Заборовська Ірина Романівна, магістр психології, ПрАТ «ВНЗ «МАУП», 02000, вул. Фрометівська, 2, м. Київ, Україна

ORCID: https//orcid.org/0000-0001-9953-1159

Туриніна Олена Леонтіївна, кандидат психологічних наук, професор кафедри психології, ПрАТ «ВНЗ «МАУП», 02000, вул. Фрометівська, 2, м. Київ, Україна

ORCID: https//orcid.org/0000-0002-3810-2040

\title{
ОСОБЛИВОСТІ ЗАСТОСУВАННЯ ГЕШТАЛЬТ-ТЕРАПЕВТИЧНОГО МЕТОДУ В ПОДОЛАННІ ПСИХОЛОГІЧНИХ ТРУДНОЩІВ КЛІЕНТІВ
}

\begin{abstract}
Анотація
Ключові слова: гештальт-терапія, психологія.

Постановка проблеми. Соціальна значущість проблеми благополуччя особистості та недостатнє вивчення можливостей застосування методів гештальт-психології у вирішенні психологічних проблем клієнтів, зумовили вибір теми нашого дослідження.

Аналіз останніх досліджень і публікацій. Значний успіх гештальту пояснюється його особливою відповідністю професійним потребам працівників соціальної сфери. Теоретично доведено, що гештальт-терапія може допомогти клієнту придбати здатність свідомо обирати свою поведінку, використовуючи різні аспекти своєї особистості, повністю реалізувати свій потенціал; що гештальт-терапія $є$ ефективним методом виховної роботи, який допомагає здоровим людям в особистісному зростанні й у реалізації їх потенційних можливостей.
\end{abstract}


Формулювання мети статті. Метою нашого дослідження стало виявлення психологічних труднощів клієнтів та визначення прийомів ітехнік гештальт-терапії з їх подолання.

Виклад основного матеріалу. Результати наших досліджень дозволяють стверджувати, що застосування методів та форм гештальттерапії щодо подолання психологічних труднощів клієнтів є безумовно ефективним.

Висновки та перспективи подальших досліджень. Достовірність та висока результативність реалізованої психокорекційної програми щодо комплексного вирішення психологічних проблем особистості за допомогою методів гештальттерапії, дозволяє рекомендувати широке застосування розробленого алгоритму та методу гештальттерапії для різних вікових груп клієнтів, які переживають кризу ідентичності, посттравматичний синдром та інші кризові стани, що супроводжуються депресією, підвищеною тривожністю, агресивністю, ворожістю, невротизацією.

\section{Аннотация}

Заборовская I. Р., магистр психологии; Туринина О. Л., кандидат психологических наук, профессор кафедрі психологии; ЧАО «ВУЗ «МАУП»; г. Киев, Украина. Особенности применения гештальттерапевтического метода в преодолении психологических проблем клиентов.

Ключевые слова: гештальт-терапия, психология.

Постановка проблемы. Социальная значимость проблемы благополучия личности и недостаточное изучение возможностей применения методов гештальт-психологии в решении психологических проблем клиентов, обусловили выбор темы нашего исследования.

Анализ последних исследований и публикаций. Значительный успех гештальта объясняется его особенным соответствием профессиональным потребностям работников социальной сферы. Теоретически доказано, что гештальт-терапия может помочь клиенту приобрести способность 
сознательно выбирать свое поведение, используя различные аспекты своей личности, полностью реализовать свой потенциал; что гештальт-терапия является эффективным методом воспитательной работы, который помогает здоровым людям в личностном росте и в реализации их потенциальных возможностей.

Формулировка цели статьи. Целью нашего исследования стало выявление психологических трудностей клиентов и определение приемов и техники гештальт-терапии по их преодолению.

Изложение основного материала. Результаты наших исследований позволяют утверждать, что применение методов и форм гештальттерапии по преодолению психологических трудностей клиентов является безусловно эффективным.

Выводы и перспективы дальнейших исследований. Достоверность и высокая результативность реализованной психокоррекционной программы по комплексному решению психологических проблем личности с помощью методов гештальттерапии, позволяет рекомендовать широкое применение разработанного алгоритма и метода гештальттерапии для различных возрастных групп клиентов, которые переживают кризис идентичности, посттравматический синдром и другие кризисные состояния, сопровождающиеся депрессией, повышенной тревожностью, агрессивностью, враждебностью, невротизации.

\begin{abstract}
Annotation
Zaborovs'ka I. R., Magister of Psychology; Turinina O. L., PhD, Professor of the Psychology Department; The Private Joint-Stock Company Higher Educational Institution Interregional Academy of Personnel Management; Kyiv, Ukraine. Features of the use of the gestalt-therapeutic method in overcoming customers' psychological problems.
\end{abstract}

Key words: gestalt therapy, psychology. 
Formulation of the problem. The social significance of the problem of individual well-being and the insufficient study of the possibilities of using Gestalt psychology methods in solving psychological problems of clients led to the choice of the topic of our research.

Analysis of recent research and publications. The significant success of the gestalt is due to its special correspondence to the professional needs of social workers. It is theoretically proven that gestalt therapy can help a client to acquire the ability to consciously choose their behavior, using various aspects of their personality, to fully realize their potential; that gestalt therapy is an effective method of educational work that helps healthy people in personal growth and in the realization of their potential.

Formulation of the purpose of the article. The aim of our study was to identify the psychological difficulties of clients and the definition of techniques and gestalt therapy techniques to overcome them.

The presentation of the main material. The results of our research suggest that the use of methods and forms of gestalt therapy to overcome the psychological difficulties of clients is unconditionally effective.

Conclusions and perspectives of further research. The reliability and high effectiveness of the implemented psycho-correction program for the complex solution of psychological problems of the individual through the methods of gestalt therapy, allows us to recommend the widespread application of the developed algorithm and the method of gestalt therapy for different age groups of clients experiencing a crisis of identity, post-traumatic syndrome and other crisis states accompanied by depression, elevated anxiety, aggression, hostility, neuroticism.

Ключові слова: гештальт-терапія, психологія.

Постановка проблеми. Гештальт-терапія дозволяє успішно вирішувати проблеми на різних рівнях, адже ії основною перевагою є цілісне бачення людини в єдності їі тілесних, емоційних, соціальних та духовних 
проявів. Гештальт-підхід застосовується не тільки в індивідуальній та груповій формах психотерапії, а й також у таких сферах, як освіта, бізнесконсультування, педагогіка, мистецтво тощо. Гештальт-терапія дозволяє швидко досягти значних та стійких результатів у вирішенні цілого спектру психологічних проблем людини.

Гештальт-терапія традиційно розглядається як найбільш ефективний метод корекції занадто нормативних, соціально скутих, стриманих індивідів (тобто тривожних, фобічних, депресивних) обмежене функціонування яких пов’язане з наявністю внутрішніх блоків.

Ціль гештальт-роботи, на думку Дж. Енрайта, полягає в тому, щоб допомогти клієнту краще усвідомлювати себе, своє сприйняття, почуття, поведінку, а також навчитися приймати відповідальність за себе та своє життя. В світовій практиці напрацьовано значний досвід у цьому напрямку, перш за все слід згадати іï засновника Ф. Перлза, Р. Резніка, М. Парлет, Ж.М. Робін, К. Рудестама, Дж. Сімкін, І. Польстер, Н. Лєбєдєву, О. Іванову, І. Булюбаша, Б. Новодержкіна, Т. Пушкіну та ін. Проте, вітчизняні практичні психологи лише останнє десятиріччя грунтовно знайомляться 3 гештальтпідходом. Таким чином, соціальна значущість проблеми благополуччя особистості та недостатнє вивчення можливостей застосування методів гештальтпсихології у вирішенні психологічних проблем клієнтів зумовили вибір теми нашого дослідження.

Аналіз останніх досліджень і публікацій. 3 метою дослідження ступеню розробленості проблеми застосування методу гештальт-терапії в сучасній психологічній науці, було проаналізовано праці провідних сучасних психологів: Ф. Перлза, Р. Резніка, М. Парлет, Ж.-М. Робін, К. Рудестама, Дж. Сімкін, І. Польстер, Н. Лєбєдєвої, О. Іванової, І. Булюбаша, Б. Новодержкіна, Т. Пушкіної та ін. Аналіз теоретичних джерел показав, що гештальт-підхід розташований на перетині: психоаналізу (Фрейд, Ференчи, Гроддек, Ранк, Адлер, Юнг, Райх, Хорні); гештальт-теорії (Еренфельц, Вертхаймер, Коффка, Келер, Голдштейн, Левін, Зейгарник); психотілесних 
видів терапії райхіанського напрямку; психодрами Морено; напрямків, які працюють із уявою й сновидіннями, у тому числі й 3 фантазіями; феноменологічного та екзистенціального підходів (Кьєркегор, Бретано, Гусерль, Хайдеггер, Шелер, Ясперс, Бубер, Тіліх, Бінсвангер, Мінковський, Марсель, Сартр, Мерло- Понті); східної філософії дзен-буддизму. Аналіз літератури, в якій освітлюється практичне застосування методик психокорекції, показав неповністю вивчені можливості використання технік гештальт-терапії у вирішенні конкретних психологічних проблем клієнтів та недостатньо широке застосування методів гештальт-терапії в практичній роботі психолога. Гештальт-терапія є ефективним методом виховної роботи, який допомагає здоровим людям в особистісному зростанні й у реалізації їх потенційних можливостей.

Як показав аналіз літератури, значний успіх гештальту пояснюється не стільки новизною методу, скільки його особливою відповідністю професійним потребам працівників соціальної сфери. Нами було розглянуто i вивчено механізми впливу методів гештальт-терапії на вирішення психологічних проблем особистості. Теоретично доведено, що гештальттерапія може допомогти клієнту придбати здатність свідомо вибирати свою поведінку, використовуючи різні аспекти своєї особистості, повністю реалізувати свій потенціал; що гештальт-терапія стає ефективним методом виховної роботи, який допомагає здоровим людям в особистісному зростанні й у реалізації їх потенційних можливостей.

Ретельне вивчення даного питання в психологічній літературі, дозволило дійти висновку, що універсальність та «життєвість» гештальттеорії дозволяє застосовувати гештальт-підхід у дуже широкому спектрі практичної психології, психіатрії, педагогіці, організаційному консультуванні, мистецтві тощо. Популярність та універсальність методу призводить до того, що багато хто з колег-психологів інших напрямків іноді навіть не підозрюють, що використовують у своїй роботі техніки гештальттерапії. Гештальт-терапія відрізняється від інших форм психологічної 
практики своєю філософією цілісності, повноти життя, проживання кожного моменту у всій його гостроті «тут і тепер». Недарма часто, коли мова іде про гештальттерапію, згадують про східну філософію, східні духовні практики. Неймовірна популярність буддизму по всьому світі свідчить про те, що ця філософська система є дуже близькою сучасній людині, а також саме для сучасної психологічної ситуації є терапевтичною. Цим також, на наш погляд, можна пояснити широке визнання та поширення гештальттерапії в країнах Заходу.

Як вважають більшість авторів, гештальт-терапія $є$ певною психотерапевтичною методологією, але в жодному разі не технологією. Із самого початку, цей метод асимілював у собі багато технік із інших психотерапевтичних систем. Гештальт - це не стільки психотерапевтичний метод, скільки стиль життя. Ціль гештальт-підходу - постійне розширення досвіду усвідомлення, і завдяки цьому досягнення більш високого рівня психічного та фізіологічного здоров'я, він дозволяє зробити життя більш наповненим відчуттями та більш свідомим, досягти нової якості буття.

Виходячи з розуміння, що внутрішні конфлікти, проблеми клієнтів, як результат незадоволення основних потреб, проявляються у вигляді підвищеної тривожності, агресивності, невротизації, соціальної фрустрованості, ми досліджували наявність саме цих проявів.

Формулювання мети статті. Метою нашого дослідження стало виявлення психологічних труднощів клієнтів та у визначенні прийомів та технік гештальттерапії з їх подолання.

Для виконання мети ми поставили такі завдання:

1. Шляхом теоретичного аналізу літератури визначити ступінь розробленості літератури 3 проблеми застосування гештальттерапії в психологічній теорії та практиці.

2. Шляхом емпіричного дослідження визначити особливості психологічних проблем, з якими звертаються клієнти до гештальттерапевта. 
3. Розробити гештальт-терапевтичну програму, як ефективне забезпечення подолання психологічних труднощів клієнта.

Для реалізації мети та завдань дослідження, нами були використані класичні прийоми та техніки групової форми проведення гештальттерапії, a також наступні психодіагностичні методики: діагностика особистісних розладів за допомогою багатофакторного опитувальника MMPI («Мінімульт»); діагностика комплексу неповноцінності особистості; діагностика ворожості особистості (за шкалою Кука-Медлей); експрес-діагностика схильності особистості до немотивованої тривожності (В. В. Бойко); експресдіагностика схильності до афективної поведінки (В. В. Бойко); діагностика рівня особистісної невротизації особистості (В. В. Бойко); діагностика рівня алекситимії особистості.

Виклад основного матеріалу. Для проведення емпіричного дослідження, ми зібрали гетерогенну гештальт-терапевтичну группу з 20 осіб віком від 21 до 45 років, 14 жінок та 6 чоловіків, різних професій та способів життя. Об’єднує учасників гештальт-терапевтичної групи, насамперед, інтерес до практичної психології загалом та гештальт-терапії зокрема, бажання дізнатися більше про себе, про мотиви власної поведінки та причини психологічних труднощів, а також прагнення до змін в особистості.

За аналізом результатів тестування вибірки, ми отримали такі результати. Діагностика особливості рівня самооцінки особистості показала, що 7\% чоловіків та $17 \%$ жінок страждають на комплекс неповноцінності, $36 \%$ чоловіків та $33 \%$ жінок мають занижену самооцінку, $50 \%$ чоловіків та $33 \%$ жінок мають адекватну самооцінку, і 7\% чоловіків у групі та 17\% жінок завищують власну самооцінку.

Великий відсоток досліджуваних (особливо серед жінок) з низькою самооцінкою свідчить про наявність психологічних труднощів у їхньому особистому та професійному житті, таких як самотність, острах майбутнього та ін. Інша крайність неадекватної самооцінки - завищена самооцінка - також 
викликає труднощі у порозумінні і з оточенням, що також призводить до самотності.

Діагностика ворожості особистості відображає підвищений рівень ворожості як серед чоловіків, так і серед жінок. А саме: за шкалою цинізму 66\% чоловіків та 7\% відсотків жінок мають високий рівень цинізму, 17\% чоловіків та 57\% жінок показали середній рівень цинізму 3 тенденцію до високого, 17\% чоловіків та 29\% жінок показали середній рівень 3 тенденцією до низького і 0\% чоловіків та 7\% жінок виявили низький рівень цинізму.

За шкалою агресивності, діагностики ворожості особистості, 33\% чоловіків та 21\% відсоток жінок мають високий рівень агресивності, 55\% чоловіків та 36\% жінок - середній з тенденцією до високого, 17\% чоловіків та 29\% жінок показали середній рівень з тенденцією до низького і тільки 0\% чоловіків та 14\% жінок - з низьким рівнем агресивності в групі.

За шкалою ворожості, 34\% чоловіків та 22\% жінок мають високий показник ворожості, 33\% чоловіків та 49\% жінок виявилися із середнім рівнем 3 тенденцією до високого, 33\% чоловіків та 22\% жінок - 3 середнім 3 тенденцією до низького, і 0\% чоловіків та 7\% показали низький рівень ворожості.

Високі показники ворожості серед опитуваних свідчать про наявність проблем у стосунках з близькими та оточенням, а саме: конфліктів, непорозуміння та відчуження. Особливо високі показники рівня ворожості для жінок гірше, ніж для чоловіків, адже жінка по своїй природі має бути більш лагідною та привітною, має вміти будувати стосунки.

Діагностика рівня алекситимії особистості показала, що лише 50\% чоловіків та 64\% жінок не страждають на алекситимію, проте 7\% чоловіків та 22\% жінок виявили досить високий показник алекситимії, що свідчить про захворюваність на психосоматичні розлади або схильність до них, і можна казати, що у 43\% чоловіків та 14\% жінок невроз. Такі показники свідчать про складність для багатьох членів гештальт-терапевтичної групи розпізнавання власних почуттів, усвідомлення власних потреб тут-і-тепер. 
На підставі аналізу отриманих емпіричних даних, можна стверджувати, що найголовнішими психологічними проблемами досліджуваних $\epsilon$ повільність, пасивність, покірність владі, приймання всього на віру, погане перенесення зміни обстановки, легка втрата рівноваги в соціальних конфліктах (шкала «іпохондрія»); чутливість, сенситивні особи, схильність до тривоги, несміливість, соромливість, не здатність прийняти самостійно рішення, не впевненість в собі (шкала «депресія»); тривожність, схильність до сумнівів, боязкість, нерішучість; низька активність, знижений настрій, низька самооцінка (шкала «психастенія»); переважаючі емоції: напруга, неспокій, стурбованість, нервозність, які виникають як емоційна реакція на стресову ситуацію та можуть бути різними за інтенсивністю та динамічністю в часі, схильність сприймати загрозу своїй самооцінці та життєдіяльності в цілому в широкому діапазоні ситуацій та реагувати вельми вираженим станом тривожності (шкала «ситуативна тривожність»); незадоволення своїми соціальними досягненнями в основних аспектах життєдіяльності; виражена емоційна збудливість, в результаті чого виникають негативні емоційні переживання (тривожність, напруга, розгубленість, роздратування) (шкала «соціальна фрустрованість»); безініціативність, егоцентрична особистісна спрямованість, що призводить до іпохондричної фіксації на соматичних відчуттях та особистісних недоліках; соціальна несміливість та залежність.

Таким чином, результати емпіричного дослідження показали, що більшість учасників гештальт-терапевтичної групи мають виразні причини для виникнення певних психологічних проблем у їхньому житті.

На нашу думку та на думку багатьох сучасних науковців, 3 метою корекції особистісного розвитку найбільш доцільно та ефективно застосовувати методи гештальт-терапії, що й було враховано нами при розробці стратегії формувального експерименту.

За аналізом результатів повторного тестування гештальт-терапевтичної групи з двадцяти осіб після проведення з ними групової гештальт-терапії, ми 
отримали результати, які відрізняються від результатів попереднього тестування.

За діагностикою особливостей рівня самооцінки особистості, відсоток чоловіків з комплексом неповноцінності знизився від 7\% до 0\%, а серед жінок 3 17\% до $0 \%$; кількість чоловіків зі зниженою самооцінкою скоротилася від 36\% до 17\%, а серед жінок - 3 33\% до 27\%; кількість чоловіків із завищеною самооцінкою залишилася незмінною, а серед жінок цей показник скоротився від 17\% до 0\%.

Відповідно до цього, кількість людей із адекватною самооцінкою зросла: серед чоловіків з 50\% до 66\%, а серед жінок з 30\% аж до 79\%.

Застосування нами методів гештальт-терапії в психотерапевтичній групі допомогло ефективно подолати такі проблеми клієнтів експериментальної групи, як тривожність, агресивність, ворожість, соціальна фрустрованість та невротизація.

Повторне тестування за діагностикою ворожості особистості відобразило зниження загального рівня ворожості як серед чоловіків, так i серед жінок.

За шкалою цинізму, діагностики рівня ворожості особистості, відсоток клієнтів з високим рівнем цинізму залишився без змін як серед чоловіків, так і серед жінок.

За шкалою агресивності, діагностики ворожості особистості, відсоток 3 високим рівнем агресивності серед чоловіків зменшився від з 33\% до 17\%, а серед жінок взагалі скоротився з 21\% до 0\%; відсоток чоловіків з середнім рівнем агресивності з тенденцією до високого зменшився з 55\% до 50\%, а у жінок цей самий показник змінився з 36\% до 21\%. 3 другого боку кількість чоловіків 3 середнім рівнем агресивності 3 тенденцією до низького збільшилася з 17\% до 33\%, а у жінок - з 29\% до 57\%; відсоток з низьким рівнем агресивності серед чоловіків залишився сталим (0\%), а у жінок кількість клієнтів з таким показником збільшилася з 14\% до 22\%. 
За шкалою ворожості, кількість чоловіків із високим рівнем ворожості скоротилася з $34 \%$ до $17 \%$, а серед жінок за цим показником - $322 \%$ до 7\%; відсоток чоловіків з середнім рівнем ворожості з тенденцією до низького також скоротився з 33\% до 17\%, а серед жінок - з 49\% до 36\%. Проте, кількість клієнтів із середнім рівнем ворожості, навпаки, зросла: серед чоловіків з $33 \%$ до $49 \%$, серед жінок - з 22\% до $36 \%$. Те ж саме стосується показників низького рівня ворожості: серед чоловіків він виріс від $0 \%$ до $17 \%$, а серед жінок - від 7\% до $21 \%$.

За діагностикою невротизації особистості, ми виявили, що середній показник рівня невротизації особистості у чоловіків знизився з 11 до 9 балів, а у жінок - з 15 до 12 балів.

Діагностика рівня алекситимії особистості показала наступні результати: відсоток клієнтів з психосоматичними розладами або схильністю до них скоротився серед жінок з 22\% до 14\%, а серед чоловіків збільшився 3 $7 \%$ до 17\%. Хворих на неврози серед чоловіків поменшало з 43\% до 17\%, а серед жінок взагалі не виявилося жодної з такими показниками. Загалом же кількість здорових від алекситимії людей збільшилася: у чоловіків з 50\% до 66\%, а серед жінок з 64 до $86 \%$.

Висновки та перспективи подальших досліджень. Таким чином, результати наших досліджень дозволяють стверджувати, що застосування методів та форм гештальттерапії щодо подолання психологічних труднощів клієнтів є безумовно ефективним, про що свідчить зниження негативних показників результатів тестування. Достовірність та висока результативність реалізованої психокорекційної програми щодо комплексного вирішення психологічних проблем особистості за допомогою методів гештальттерапії дозволяє рекомендувати широке застосування розробленого алгоритму та методу гештальттерапії для різних вікових груп клієнтів, які переживають кризу ідентичності, посттравматичний синдром та інші кризові стани, що супроводжуються депресією, підвищеною тривожністю, агресивністю, ворожістю, невротизацією. 


\section{Список використаних джерел}

1. Гронський А. Екзістенціальні фігури гуштальту / А. Гронський.- М: Генезис, 2007.- 213c.

2. Гронський А. Класична гештальт-група / А. Гронський.- М.: Сфера, 2001.- $243 \mathrm{c}$.

3. Домбровський А. Гештальт-терапія наркотичної залежності / A. Домбровський.- М.: Генезис, 2009.- 227c.

4. Долгополов М. Гештальт-підхід у роботі з організаціями / M. Долгополов.- СПб: Пітер, 2003.- 178c.

5. Перлз Ф. Гештальт-Підхід і Свідок Терапії / Ф. Перлз.- М.: Сфера, 2002.- 97c.

6. Туриніна О. Л. Психологія травмуючих ситуацій / О. Л. Туриніна.- К.: ДП «ВД «Персонал», 2012. - 136 с.

\section{References}

1. Hrons'kyy, A. (2007), Ekzistentsial'ni fihury hushtal'tu [Existential figures of the gushtalt], Henezys, Moscow, Russia.

2. Hrons'kyy, A. (2001), Klasychna heshtal't-hrupa [Classical Gestalt Group], Sfera, Moscow, Russia.

3. Dombrovs'kyy, A. (2009), Heshtal't-terapiya narkotychnoyi zalezhnosti [Gestalt-therapy of narcotic addiction], Henezys, Moscow, Russia.

4. Dolhopolov, M. (2003), Heshtal't-pidkhid u roboti $z$ orhanizatsiyamy [Gestalt-approach to work with organizations], Piter, $\mathrm{SPb}$, Russia.

5. Perlz, F. (2002), Heshtal't-Pidkhid i Svidok Terapiyi [Gestalt-Approach and A Witness of Therapy], Sfera, Moscow, Russia.

6. Turynina, O. L. (2012), Psykholohiya travmuyuchykh sytuatsiy [Psychology of traumatic situations], DP «VD «Personal», Kyiv, Ukraine. 